\title{
Nutritional availability of methionine, lysine and tryptophan in fish meals, as assessed with biological, microbiological and dye-binding assay procedures
}

\author{
BY D. HEWITT AND J. E. FORD \\ National Institute for Research in Dairying, \\ Shinfield, Reading RG2 9 AT
}

\section{(Received 31 August 1984 - Accepted 28 November 1984)}

1. In vitro assay procedures were applied in the measurement of available amino acids in a selection of fish meals representing good- and poor-quality product. Results were assessed by comparing them with results from chick-growth assays.

2. Available methionine and tryptophan were assayed microbiologically with Streptococcus zymogenes, after predigestion of the test samples with papain or pronase. Results for methionine were correlated with chick-growth assays ( $r 0.86$ for papain, 0.91 for pronase; $P<0.01$ ). Compared with the chick assays, papain tended to give lower, and pronase higher, results. Finer milling of the test samples did not influence the pronase values.

3. Results for available tryptophan were also correlated with chick-growth assays ( $r 0.95$ for papain, 0.96 for pronase; $P<0.001$ ). Compared with the chick values, papain gave markedly lower results and pronase marginally higher ones. Finer milling of the test samples increased the papain values by about $50 \%$ but had no effect with pronase.

4. Available lysine was assayed microbiologically with Tetrahymena pyriformis and with a dye-binding procedure (DBL). The results correlated with the chick-growth assays $(r 0.99$ for $\mathrm{DBL}, P<0.001 ; 0.85$ for Tetrahymena, $P<0.01$ ) but both methods overrated the poorer-quality samples.

5. True nitrogen digestibilities and amino acid digestibilities were determined with chickens by the ileal analysis' procedure: the amino acid digestibilities were significantly higher and similar to the corresponding availabilities as measured in chick-growth assays.

6. Ball milling a poor-quality fish meal caused a marked fall in its $\mathbf{N}$ digestibility, whereas similar treatment of a good-quality meal caused a slight increase. An explanation for this finding is proposed.

7. Strep. zymogenes assays following pronase digestion of the test samples gave precise and acceptably accurate measures of the biologically available methionine and tryptophan in the test samples. For available lysine, Tetrahymena and DBL values for the poorer-quality samples were notably higher than the chick-growth assay; possible reasons for this are discussed. The ileal analysis procedure underestimated true $\mathrm{N}$ digestibility.

For some protein sources the 'total' amino acid composition may be misleading as a guide to the nutritional quality; for example, meats and meat products that have been subjected to severe heating during manufacture; canned foods containing reducing sugars, in which protein quality may be degraded by Maillard-type reactions during processing and subsequent storage; and seeds of certain pulses and cereals, in which interaction of tannins with the seed proteins may impair the digestibility. To evaluate such materials we need reliable methods for analysing their content of biologically available amino acids, especially of lysine, methionine and tryptophan which are commonly in short supply.

Measurement of amino acid availability in growth tests with laboratory animals is not practicable for routine quality control except insofar as it is necessary for the validation of quicker and more precise in vitro methods. Among these, a rapid dye-binding procedure for the measurement of available lysine has aroused much interest, having been recommended as a replacement for more complex procedures that involve hydrolysis of the test protein and labelling of the reactive lysine units with a nitrophenyl or pyridyl group (Hurrell et al. 1979). To assess this method, the International Association of Fish Meal Manufacturers (IAFMM) organized a collaborative test in which in vitro assays for total lysine, dye-binding lysine (DBL), dye-binding capacity (DBC) and FDNB-lysine were applied to eight fish 
meals, and the results compared with those for available lysine from chick-growth assays (Barlow et al. 1984). The present study extends this work to include an evaluation of microbiological assays for available methionine, tryptophan and lysine. The results were again assessed by comparing them with those from chick-growth assays.

Digestibility is a major, though not the only, factor in determining the availability of amino acids in food proteins. In the present work it was measured with chickens by a modification of the ileal digestibility procedure of Varnish \& Carpenter (1975). For three of the fish meals, two of good and one of sub-standard quality, the digestibility of the protein and of its constituent amino acids was determined, and also the influence of fineness of grinding of the fish meals.

\section{MATERIALS AND METHODS}

Fish meals. Eight fish meals were examined, products of commercial production from Denmark, USA, Peru, Norway and South Africa, and they are described by Barlow et al. (1984). The meals, which included samples that had been selected as being of sub-standard quality, had been ground in a mechanical pestle and mortar. A portion of each sample was further milled to pass an 80 mesh sieve by treatment for $30 \mathrm{~min}$ in a reciprocatory ball mill.

Assays with Streptococcus zymogenes. Available methionine and tryptophan were assayed by the general procedure described by Boyne et al. (1975), in which papain (Koch-Light Laboratories Ltd, Colnbrook, Bucks) predigestion of the test samples is employed. Additional assays were carried out using pronase (B grade, Calbiochem Ltd, London) instead of papain for the predigestion, as follows. A weight of test sample calculated to contain $50 \mathrm{mg}$ nitrogen was suspended in $20 \mathrm{ml}$ sodium $\beta$-glycerophosphate solution $(20 \mathrm{~g} / 1)$. The $\mathrm{pH}$ value was adjusted to 8.0 and $2 \mathrm{ml}$ pronase $(10 \mathrm{~g} / 1$ in the glycerophosphate solution) added. The mixture was incubated at $48^{\circ}$ for $3 \mathrm{~h}$ in an end-over-end shaker (Ford, 1964) and then adjusted to $\mathrm{pH} 7.2$ and diluted with water to $500 \mathrm{ml}$.

'Total' methionine also was assayed microbiologically. To samples (50 mg N) in $250-\mathrm{ml}$ conical flasks were added $50 \mathrm{ml} 3 \mathrm{M}$-hydrochloric acid. The flasks were covered and heated in a steam autoclave for $16 \mathrm{~h}$ at $115^{\circ}$, cooled and neutralized by slow addition of $1 \mathrm{M}$-sodium hydroxide with stirring. The hydrolysates were diluted to 1 litre and filtered, and assayed against a standard solution containing $10 \mu \mathrm{g} \mathrm{L}$-methionine $/ \mathrm{ml}$ in $0.15 \mathrm{M}$-sodium chloride.

For the assay of total tryptophan the test samples were hydrolysed with alkali. Each sample ( $100 \mathrm{mg} \mathrm{N}$ ) was mixed with $15.4 \mathrm{~g}$ barium hydroxide octahydrate and $9 \mathrm{ml}$ boiled water in a $150 \mathrm{ml}$ polypropylene flask. A replicate sample was mixed with $9 \mathrm{ml}$ water containing $5 \mathrm{mg}$ DL-tryptophan. The flasks were covered and heated for $7 \mathrm{~h}$ at $121^{\circ}$ in a steam autoclave. After cooling, the hydrolysates were adjusted to $\mathrm{pH} 6.0$ by slow addition of $5 \mathrm{M}$-sulphuric acid, diluted to $500 \mathrm{ml}$ and filtered through Whatman no. 1 paper. The filtrate was adjusted to $\mathrm{pH} 7.2$ and assayed against a standard solution containing $10 \mu \mathrm{g}$ DL-tryptophan $/ \mathrm{ml}$.

Assays with Tetrahymena pyriformis. Available lysine and methionine were assayed as described by Shorrock (1976). The test digests were prepared as for the Strep. zymogenes methionine assays, but at a lesser final dilution.

Measurement of $D B L$. The method of Hurrell et al. (1979) was used, essentially as specified in the instructions to participants in the IAFMM collaborative study (Barlow et al. 1984). Early trials were carried out with an automated commercial apparatus (Jacobsen et al. 1972) but, with experience of the procedure, this apparatus was rejected in favour of ordinary laboratory equipment. A laboratory shaker was used to mix the test reagents with the meal samples, and the optical density of the dye solutions was measured with a spectrophotometer. The tests were done in duplicate, by use of this modified method. 


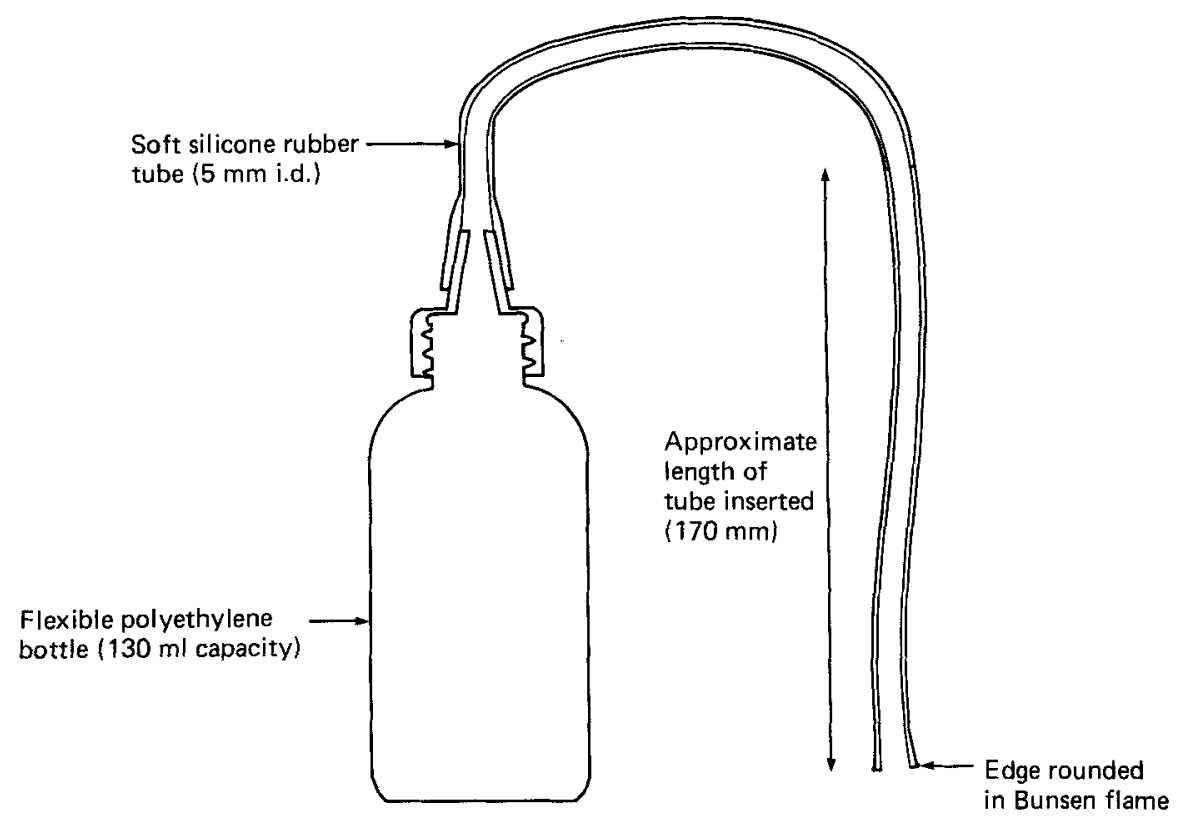

Fig. 1. Device for introducing test meals into the crop of the chickens.

Chick-growth assays for available methionine, lysine and tryptophan. Assays for available methionine and lysine were done as described by Achinewhu \& Hewitt (1979) except that the salt mixture was that of Hewitt et al. (1973). Available tryptophan was assayed in an analogous manner, using diets in which the principal ingredients were as specified by Harwood \& Shrimpton (1969). Only four fish meals could be accommodated in each assay and so the eight meals were divided randomly into two sets of four which were assayed consecutively. Amino acid potencies were derived from feed conversion efficiency results by the slope-ratio method (Finney, 1978).

Ileal digestibility measurements. Ford \& Hewitt (1979) modified the method of Varnish $\&$ Carpenter (1975). Chickens were first accustomed to eating their food in two $2 \mathrm{~h}$ periods each day. They were then offered a protein-free diet during these same periods for $2 \mathrm{~d}$, and on the third day they were offered the test meal. Voluntary intake of the protein-free diet during the $2 \mathrm{~d}$ pre-experiment period varied greatly between the birds, and on the day of the experiment some birds, notably those on protein-free diets and certain unpalatable test diets, refused to eat or ate so slowly that the test meal remained largely uneaten at the end of the $2 \mathrm{~h}$ feeding period. These animals were rejected from the experiment.

The procedure was considered therefore to be still unsatisfactory, and to overcome some of the practical difficulties it was further modified, as follows. Standard chicken mash was offered $a d l i b$. up to $24 \mathrm{~h}$ before the experiment and was then taken away. On the day of the experiment the test meals (equivalent to approximately $18 \mathrm{~g} / \mathrm{kg}$ average body-weight of the birds on the experiment) were weighed into soft plastic bottles and mixed with water to form a slurry. The bottles were then fitted with a screw nozzle to which was fitted a soft plastic extension tube (Fig. 1). This was gently eased down the oesophagus and into the crop, and the contents of the bottle were squeezed out as completely as possible. The birds were returned to their cages and $3 \mathrm{~h}$ later they were killed and the contents of the lower ileum collected as described by Ford \& Hewitt (1979).

The fish meals were incorporated in a semi-purified diet to give $200 \mathrm{~g}$ crude protein 
Table 1. Total and available methionine $(\mathrm{g} / 160 \mathrm{~g}$ nitrogen $)$ in the test fish meals

(Mean values with their standard errors)

\begin{tabular}{|c|c|c|c|c|c|c|c|c|c|c|c|}
\hline \multirow{4}{*}{$\begin{array}{l}\text { Fish } \\
\text { meal }\end{array}$} & \multicolumn{7}{|c|}{ Streptococcus zymogenes assays } & \multirow{2}{*}{\multicolumn{4}{|c|}{$\frac{\text { Tetrahymena pyriformis assays }}{\text { Available }}$}} \\
\hline & \multirow{2}{*}{\multicolumn{2}{|c|}{ Total $\neq$}} & \multicolumn{5}{|c|}{ Available } & & & & \\
\hline & & & \multicolumn{3}{|c|}{$\begin{array}{c}\text { Pronase } \\
\text { predigestion* }\end{array}$} & \multicolumn{2}{|c|}{$\begin{array}{c}\text { Papain } \\
\text { predigestion* }\end{array}$} & \multicolumn{2}{|c|}{$\begin{array}{c}\text { Pronase } \\
\text { predigestion } \dagger\end{array}$} & \multicolumn{2}{|c|}{$\begin{array}{c}\text { Papain } \\
\text { predigestion } \dagger\end{array}$} \\
\hline & 1 & 2 & Mean & SEM & $\S$ & Mean & SEM & & $\|$ & & $\|$ \\
\hline A & $32 \cdot 0$ & $33 \cdot 1$ & $31 \cdot 6$ & 0.34 & $(32 \cdot 3)$ & $25 \cdot 7$ & 0.92 & $30 \cdot 5$ & $(30 \cdot 7)$ & $21 \cdot 3$ & $22 \cdot 5)$ \\
\hline B & $29 \cdot 7$ & $29 \cdot 5$ & $29 \cdot 5$ & 0.76 & $(29 \cdot 3)$ & $23 \cdot 6$ & 0.97 & $30 \cdot 2$ & $(28 \cdot 1)$ & $21 \cdot 9$ & $20 \cdot 5)$ \\
\hline C & $27 \cdot 6$ & 27.8 & $18 \cdot 0$ & $\mathrm{I} \cdot 15$ & $(21 \cdot 0)$ & $10 \cdot 9$ & 0.91 & $16.7^{\prime}$ & $(15 \cdot 4)$ & $8 \cdot 1$ & $7 \cdot 7)$ \\
\hline $\mathrm{D}$ & $29 \cdot 3$ & $30 \cdot 6$ & $28 \cdot 3$ & 0.27 & $(28 \cdot 5)$ & $21 \cdot 6$ & 0.65 & $27 \cdot 2$ : & $(28 \cdot 0)$ & 21.8 & $(19.8)$ \\
\hline $\mathrm{E}$ & $29 \cdot 4$ & $29 \cdot 4$ & 27.0 & 0.50 & $(28 \cdot 3)$ & $23 \cdot 6$ & $1 \cdot 40$ & $27 \cdot 0$ & $(25 \cdot 8)$ & $23 \cdot 4$ & $(22 \cdot 5)$ \\
\hline $\mathrm{F}$ & 29.7 & $30 \cdot 3$ & $29 \cdot 4$ & 0.88 & $(29 \cdot 7)$ & $26 \cdot 9$ & 0.98 & $28 \cdot 1$ & $(27 \cdot 6)$ & $21 \cdot 0$ & $(22 \cdot 7)$ \\
\hline$G$ & $25 \cdot 6$ & $25 \cdot 8$ & $24 \cdot 2$ & $1 \cdot 13$ & $(23 \cdot 6)$ & 18.9 & $1 \cdot 01$ & $23 \cdot 8$ & $(21 \cdot 2)$ & $17 \cdot 7$ & $(14.8)$ \\
\hline $\mathrm{H}$ & $26 \cdot 0$ & $28 \cdot 4$ & $24 \cdot 0$ & 0.64 & $(23.6)$ & 19.8 & 0.82 & $22 \cdot 0$ & $(22 \cdot 6)$ & $14 \cdot 5$ & $(16 \cdot 4)$ \\
\hline
\end{tabular}

* Based on six assays.

† Single assays.

Results for two independent assays.

$\S$ The test sample was further ground in a ball mill to pass an 80 mesh sieve, before digestion with pronase; single assay.

II Results of Strep. zymogenes assays on the same test digests.

$(\mathrm{N} \times 6.25) / \mathrm{kg}$ except in Expt 3(b) where the influence of test protein level was investigated. The test diets and the corresponding ileal contents were analysed for chromic oxide, $\mathrm{N}$ and amino acids, and the true ileal digestibilities of $\mathrm{N}$ and amino acids calculated.

\section{RESULTS}

Tests in vitro

Methionine. Table 1 shows the results of microbiological assays for total and available methionine in the fish meals. Two assays for total methionine were independent inasmuch as they were done on separate occasions and on different digests of the test samples. Recovery tests were not included in the assays, as in our experience with fish meals there is no significant loss of added methionine during the relatively-mild hydrolysis procedure employed. Available methionine was measured with Strep. zymogenes and also with Tetrahymena, after predigestion of the test samples either with papain or with pronase. For Strep. zymogenes the result is the mean of six replicate assays. For Tetrahymena the assays were done only once, and the results are presented for comparison with the corresponding values obtained for the same test digests with Strep. zymogenes.

For most of the assays the fish meals were used 'as received', but for one assay they were ground finer by treatment in a ball mill before digestion with pronase.

With Strep. zymogenes the 'pronase' values were similar to or marginally lower than the corresponding 'total' values, except for fish meal $\mathrm{C}$ for which the pronase value was only $65 \%$ of the total. Finer milling of the test samples before pronase digestion increased this to $76 \%$. The papain values were between 75 and $90 \%$ of the corresponding total values, again except for fish meal $\mathrm{C}$ for which the value was $39 \%$. 
Table 2. Total and available tryptophan ( $\mathrm{g} / 160 \mathrm{~g}$ nitrogen) in the test fish meals

\begin{tabular}{|c|c|c|c|c|c|c|c|c|c|c|c|}
\hline \multirow{3}{*}{$\begin{array}{l}\text { Fish } \\
\text { meal }\end{array}$} & \multicolumn{5}{|c|}{ Total } & \multicolumn{5}{|c|}{ Available* } & \\
\hline & \multicolumn{2}{|c|}{$\begin{array}{l}\text { Microbiological } \\
\text { assay* } \dagger\end{array}$} & \multicolumn{3}{|c|}{ Chemical assays $\ddagger$} & \multicolumn{3}{|c|}{$\begin{array}{c}\text { Pronase } \\
\text { predigestion }\end{array}$} & \multicolumn{3}{|c|}{$\begin{array}{c}\text { Papain } \\
\text { predigestion }\end{array}$} \\
\hline & 1 & 2 & A & B & $\mathrm{C}$ & 1 & 2 & $\S$ & 1 & 2 & $\S$ \\
\hline A & $11 \cdot 7$ & $12 \cdot 5$ & $11 \cdot 3$ & $9 \cdot 2$ & $11.9^{\circ}$ & $10 \cdot 7$ & $12 \cdot 3$ & $(11 \cdot 7)$ & $6 \cdot 1$ & $6 \cdot 6$ & $(9 \cdot 2)$ \\
\hline B & $8 \cdot 8$ & $10 \cdot 1$ & 9.9 & $8 \cdot 5$ & 9.6 & 8.6 & $10 \cdot 4$ & $(9 \cdot 4)$ & $5 \cdot 1$ & $6 \cdot 0$ & $(7.4)$ \\
\hline C & $7 \cdot 8$ & 8.5 & $9 \cdot 4$ & $6 \cdot 3$ & $10 \cdot 5$ & 4.9 & $6 \cdot 2$ & $(6 \cdot 5)$ & $1 \cdot 3$ & 1.4 & $(3 \cdot 1)$ \\
\hline D & $9 \cdot 6$ & $10 \cdot 5$ & $10 \cdot 2$ & $8 \cdot 2$ & 9.9 & $8 \cdot 2$ & $10 \cdot 6$ & $(9 \cdot 1)$ & $4 \cdot 6$ & 4.9 & $(6 \cdot 3)$ \\
\hline $\mathrm{E}$ & $9 \cdot 9$ & $10 \cdot 3$ & 9.8 & 9.0 & $9 \cdot 8$ & $8 \cdot 7$ & $10 \cdot 4$ & $(9 \cdot 6)$ & $5 \cdot 8$ & $6 \cdot 6$ & $(8.8)$ \\
\hline $\mathrm{F}$ & 11.0 & $10 \cdot 7$ & $11 \cdot 2$ & $8 \cdot 2$ & $11 \cdot 4$ & $9 \cdot 2$ & 11.8 & $(10 \cdot 1)$ & 6.4 & $8 \cdot 1$ & (8.9) \\
\hline G & 9.0 & $9 \cdot 2$ & 11.4 & $7 \cdot 6$ & $8 \cdot 3$ & $7 \cdot 4$ & $8 \cdot 3$ & $(7 \cdot 6)$ & $3 \cdot 1$ & 3.8 & $(5 \cdot 2)$ \\
\hline $\mathrm{H}$ & $8 \cdot 2$ & $8 \cdot 4$ & $9 \cdot 5$ & $6 \cdot 3$ & $7 \cdot 4$ & $7 \cdot 6$ & 7.9 & $(7 \cdot 3)$ & $4 \cdot 1$ & $4 \cdot 3$ & (5.9) \\
\hline
\end{tabular}

* Assayed microbiologically with Streptococcus zymogenes; two assays.

$\dagger$ Values were not corrected for recovery of added DL-tryptophan. For details, see below.

$\ddagger$ Assay procedures: (A) Slump \& Schreuder (1969); (B) Spies (1967); (C) Miller (1967).

$\S$ The test samples were further ground in a ball mill to pass through an 80 mesh sieve, before enzymic digestion.

Results obtained with Tetrahymena were closely similar to those with Strep. zymogenes. With both micro-organisms the papain pretreatment gave consistently lower values.

Tryptophan. Table 2 shows the results of Strep. zymogenes assays for total and available tryptophan and, for comparison, values for total tryptophan contributed to the IAFMM collaborative study by three different laboratories and obtained by use of three different chemical assay procedures. These latter values were kindly provided by the IAFMM.

In the microbiological assays for total tryptophan, recovery of added DL-tryptophan was widely variable $(74-101 \%$, mean $88 \%$ ), equally with duplicated assays 'within samples' as with comparisons 'between samples'. After correction for recovery, these total values seemed unduly high. They were about $20 \%$ higher than the means of the corresponding three chemical assay values and, when compared with the 'available' values, they indicated that the ratio total:available amino acid was higher for tryptophan than for lysine and methionine. It is conceivable that the alkaline-hydrolysis caused greater loss of added DL-tryptophan than of the protein-bound tryptophan in the test samples. It might also be that the alkaline-hydrolysis did not completely racemize the tryptophan in the test samples and that the excess of L-tryptophan caused higher growth responses in the assays. Against this, the uncorrected 'totals' were in general only marginally higher than the 'available' values obtained after pronase digestion of the test samples. For this reason, these uncorrected values have been taken as our best measure of total tryptophan.

Results for available tryptophan were strongly influenced by the method of enzymic predigestion employed and by the fineness of grinding of the test samples. Papain gave values that ranged from 17 to $67 \%$ of the corresponding uncorrected totals. With finer milling of the test samples the values increased, from 38 to $85 \%$. Pronase gave much higher results. They ranged from 68 to $101 \%$ of the total values and were not increased when the test samples were milled more finely. 
Table 3. Protein and amino acid digestibility coefficients as measured in chickens by the ileal analysis procedure

(a) Protein and amino acid digestibilities, and effects of finer milling of the test samples (four observations per test diet)

\begin{tabular}{|c|c|c|c|c|c|c|c|c|}
\hline & \multicolumn{2}{|c|}{$\begin{array}{c}\text { Fish meal } \\
\text { A }\end{array}$} & \multirow{2}{*}{$\begin{array}{c}\text { Fish meal } \\
\text { B }\end{array}$} & \multirow{2}{*}{$\begin{array}{l}\text { Fish meal } \\
\text { B, ball- } \\
\text { milled }\end{array}$} & \multirow{2}{*}{$\begin{array}{c}\text { SE of } \\
\text { difference } \\
\text { between 'B' } \\
\text { means }\end{array}$} & \multirow{2}{*}{$\begin{array}{l}\text { Fish meal } \\
\text { C }\end{array}$} & \multirow{2}{*}{$\begin{array}{l}\text { Fish meal } \\
\mathrm{C} \text {, ball- } \\
\text { milled }\end{array}$} & \multirow{2}{*}{$\begin{array}{c}\text { SE of } \\
\text { difference } \\
\text { between ' } C \text { ' } \\
\text { means }\end{array}$} \\
\hline & Mean & $\mathbf{S E}$ & & & & & & \\
\hline $\begin{array}{l}\text { Crude protein } \\
\text { (nitrogen } \times 6.25 \text { ) }\end{array}$ & 0.89 & 0.008 & 0.80 & $0 \cdot 90^{* *}$ & 0.023 & 0.63 & $0 \cdot 27^{* *}$ & 0.089 \\
\hline Aspartic acid & 0.88 & 0.017 & 0.77 & $0.85^{*}$ & 0.024 & 0.64 & $0 \cdot 28^{* *}$ & 0.088 \\
\hline Threonine & 0.95 & 0.016 & 0.86 & 0.90 & 0.027 & 0.69 & $0.38^{*}$ & 0.155 \\
\hline Serine & 0.94 & 0.017 & 0.81 & 0.88 & 0.042 & 0.65 & $0.25^{*}$ & $0 \cdot 147$ \\
\hline Glutamic acid & 0.94 & 0.008 & 0.86 & $0.92^{*}$ & 0.022 & 0.67 & $0.31^{*}$ & $0 \cdot 132$ \\
\hline Proline & 0.95 & 0.007 & 0.93 & 0.93 & 0.034 & 0.79 & $0.52 * *$ & 0.046 \\
\hline Glycine & 0.90 & 0.012 & 0.83 & $0.89^{* *}$ & 0.016 & 0.71 & $0.45^{* *}$ & 0.063 \\
\hline Alanine & 0.95 & 0.007 & 0.87 & $0.93^{* *}$ & 0.011 & 0.70 & $0.36^{*}$ & $0 \cdot 120$ \\
\hline Valine & 0.94 & 0.005 & 0.87 & $0.94^{* *}$ & 0.018 & 0.73 & $0.41^{*}$ & 0.122 \\
\hline Methionine & 0.94 & 0.010 & 0.91 & 0.94 & 0.026 & 0.77 & $0.42 *$ & $0 \cdot 127$ \\
\hline Isoleucine & 0.94 & 0.013 & 0.88 & $0.93^{*}$ & 0.020 & 0.65 & 0.42 & $0 \cdot 198$ \\
\hline Leucine & 0.94 & 0.006 & 0.88 & $0.93^{*}$ & 0.014 & 0.70 & $0.36^{*}$ & $0 \cdot 120$ \\
\hline Phenylalanine & 0.95 & 0.007 & 0.87 & 0.93 & 0.029 & 0.68 & 0.40 & 0.116 \\
\hline Histidine & 0.93 & 0.012 & 0.87 & 0.90 & 0.033 & 0.69 & 0.40 & $0 \cdot 127$ \\
\hline Lysine & 0.94 & 0.010 & 0.89 & $0.94^{*}$ & 0.014 & 0.70 & $0.30^{* *}$ & $0 \cdot 110$ \\
\hline Arginine & 0.96 & 0.013 & 0.91 & 0.94 & 0.017 & 0.75 & $0.46^{*}$ & 0.082 \\
\hline
\end{tabular}

The effect of ball-milling was statistically significant: ${ }^{*} P<0.05,{ }^{* *} P<0.01$.

(b) Effects of varying the test protein concentration on digestibility of good and poor quality fish meals (six observations per diet except where noted in parentheses)

\begin{tabular}{ccc}
\hline Fish meal... & A (good quality) & C (poor quality) \\
\hline Protein in test diet $(\mathrm{g} / \mathrm{kg})$ & $0.87(5)$ & \\
63 & 0.88 & 0.49 \\
126 & 0.89 & 0.67 \\
189 & $0.013(n 6)$ & 0.53 \\
Pooled SE & 14 & 0.081 \\
$\mathrm{df}$ & \\
\hline
\end{tabular}

\section{Ileal digestibilities of $N$ and amino acids}

Table $3(a)$ shows the coefficients of digestibility of protein and amino acids in fish meals $A$ and $B$ (good quality) and C (poor quality). True digestibility values were determined for fifteen individual amino acids (analyses for tryptophan, cystine and tyrosine were not available). In general, the true amino acid digestibility values were fairly uniform and about $5 \%$ higher then those for protein. An exception was the ball-milled fish meal $\mathrm{C}$ for which the average true digestibility of amino acids was $30 \%$ higher than the true $N$ digestibility.

The effect of finer milling of fish meals $B$ and $C$ was examined. With fish meal $B$, the $\mathrm{N}$ digestibility was increased from 0.80 to $0.90(P<0.01)$ but with fish meal $\mathrm{C}$, to our surprise, the digestibility was markedly reduced, from 0.63 to $0.27(P<0.01)$.

It seemed possible that ileal digestibilities might be influenced by the amount of protein 
Table 4. Available methionine, lysine and tryptophan ( $\mathrm{g} / 160 \mathrm{~g}$ nitrogen) in fish meals, as determined by chick-growth assay

(Mean values with their standard errors: values in parentheses are contents of available amino acid as a proportion of 'total' amino acid content. 'Total' lysine values from Barlow et al. (1984), 'total' methionine and tryptophan values from Tables 1 and 2 respectively)

\begin{tabular}{|c|c|c|c|c|c|c|}
\hline \multirow{2}{*}{$\begin{array}{l}\text { Fish } \\
\text { meal }\end{array}$} & \multicolumn{2}{|c|}{ Methionine } & \multicolumn{2}{|c|}{ Lysine } & \multicolumn{2}{|c|}{ Tryptophan } \\
\hline & Mean & SE & Mean & $\mathrm{SE}$ & Mean & SE \\
\hline A & $32 \cdot 3$ & $3.4(0.99)$ & $76 \cdot 3$ & $6.9(0.94)$ & $10 \cdot 4$ & $0.80(0.86)$ \\
\hline B & $24 \cdot 6$ & $2.8(0.83)$ & $69 \cdot 4$ & $6.6(0.94)$ & $7 \cdot 3$ & $0.79(0.77)$ \\
\hline C & $14 \cdot 6^{*}$ & $5.0(0.53)$ & $29 \cdot 1^{*}$ & $13.9(0.47)$ & $2 \cdot 8$ & $0.73(0.34)$ \\
\hline D & $30 \cdot 0$ & $3.2(1.00)$ & $76 \cdot 2$ & $4.4(0.99)$ & 8.9 & $0.81(0.89)$ \\
\hline $\bar{E}$ & $26 \cdot 7$ & $3.0(0.91)$ & $78 \cdot 5$ & $4.4(1.04)$ & $9 \cdot 3$ & $0.70(0.93)$ \\
\hline$F$ & $28 \cdot 8$ & $3 \cdot 1(0 \cdot 96)$ & 86.8 & $4.5(1.09)$ & $10 \cdot 3$ & $0.70(0.95)$ \\
\hline G & $17 \cdot 0$ & $2 \cdot 1(0 \cdot 66)$ & $48.9 *$ & $13.1(0.78)$ & 5.9 & $0.77(0.65)$ \\
\hline $\mathrm{H}$ & 21.6 & $2.5(0.79)$ & $62 \cdot 8$ & $4.2(0.93)$ & $6 \cdot 6$ & $0.69(0.80)$ \\
\hline
\end{tabular}

* Some evidence (not significant, $P>0.05$ ) of non-linear response to increase in the level of fish meal. Result calculated from the lower of two test levels (see below).

given with the test meal, and to check on this two of the fish meals, $A$ and $C$, representing good- and poor-quality product, were incorporated into diets at 63,126 and $189 \mathrm{~g}$ crude protein $(\mathrm{N} \times 6.25) / \mathrm{kg}$. The results (Table $3(b))$ with the good-quality meal $(\mathrm{A})$ showed that the digestibility was not influenced by the content of protein in the test meal. With the poor-quality meal (C) the findings were less consistent but they indicated no systematic effect of protein dosage on protein digestibility.

\section{Availability of methionine, tryptophan and lysine as measured in chick growth assays}

Table 4 shows values for biologically-available lysine, methionine and tryptophan in the eight fish meals as measured in growth assays with chicks. Results are expressed as $\mathrm{g} / 160 \mathrm{~g} \mathrm{~N}$ and also (in parentheses) as proportions of the corresponding 'total' values. In general, the availability of all three amino acids was high (0.77-1.09), except for the sub-standard fish meals $C$ and $G$ in which the amino acid availability values ranged from 0.34 to 0.53 and 0.65 to 0.78 respectively. In the lysine assays of these two fish meals, and in the methionine assay of fishmeal $\mathrm{C}$, different results were obtained with different levels of inclusion of the two meals in the test diets. The lower level of inclusion gave markedly higher results and it is these that are given in Table 4. This decision was arbitrary, since the assays were statistically valid. It was made on the assumption that the fall-off in response indicated the presence of growth-depressing factors in the meals. There was no such indication of non-linearity in the tryptophan assay, although the availability of tryptophan was similarly low.

\section{DISCUSSION}

Fig. 2 illustrates a comparison of the Strep. zymogenes and chick-growth assays for available methionine. The plots show that the choice of enzyme used in the microbiological tests affected the relation of the results to the chick-assay values. Compared with pronase, papain consistently gave lower results with Tetrahymena as with Strep. zymogenes (Table 1). With papain, the Strep. zymogenes values were slightly lower than the chick assays, and with pronase they were slightly higher. Correlations were high in both cases (papain, $r$ 0.86; pronase, $r 0.91 ; P<0.01$ ). Miller et al. (1965) found that available methionine values 


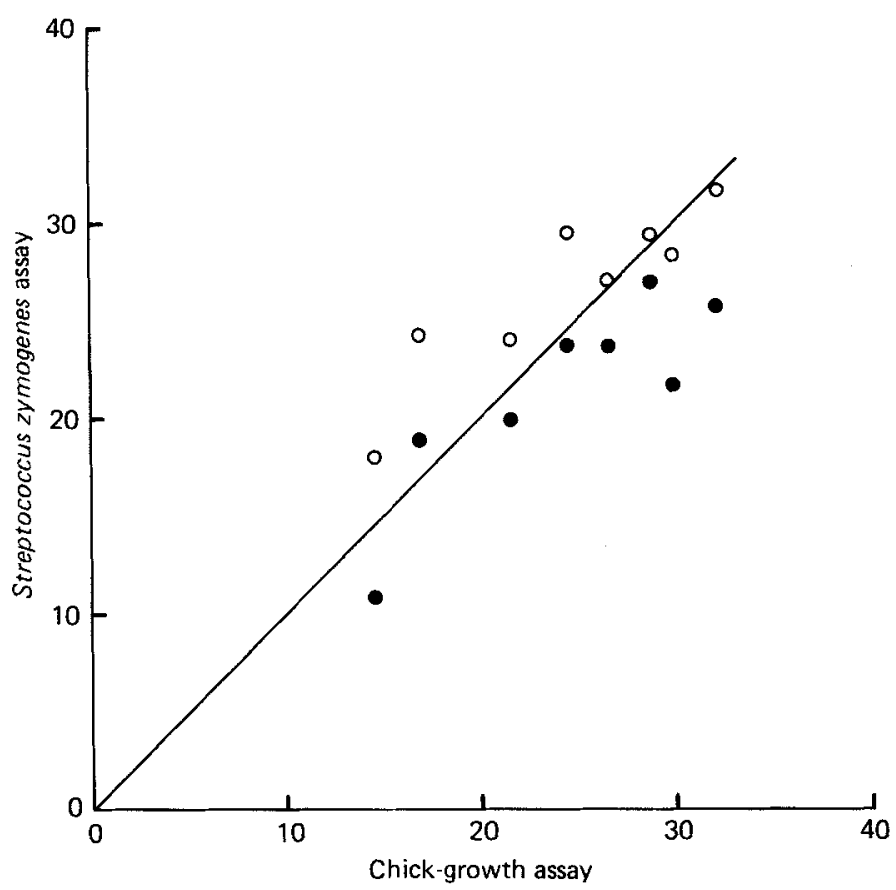

Fig. 2. Available methionine ( $\mathrm{g} / 160 \mathrm{~g}$ nitrogen) in eight fish meals as determined with Streptococcus zymogenes following predigestion with pronase $(O)$ or papain $(\bullet)$, in relation to chick-growth-assay values. The line on the graph indicates equality of values.

obtained with Strep. zymogenes were initially lower than those obtained with chicks, but agreed closely with the chick results when a higher concentration of papain was used in the preparation of the samples for test. Our present experience is that pronase tended to give higher results than papain, especially with the poorer samples. It may be that these marginally-higher values for methionine in fish meals are no better as predictions of biological availability. Even so, it seems that results obtained with papain for certain classes of food proteins may be misleadingly low and it is timely to reassess the procedure for preparing samples for the microbiological assays.

Experience in the authors' laboratory with cereals and pulses, milk and milk products, mixed diets, and meat and fish meals, recommends the adoption of pronase as the digesting enzyme. Papain gives unduly low results with cereals, partly because the glutelins are poorly soluble except at alkaline $\mathrm{pH}$ and are better digested by pronase or other alkaline protease (Ford \& Hewitt, 1979). Fineness of grinding of the test sample may also strongly influence the results where, as in rice, the endosperm protein is mainly present as discrete particles in the interstices between the compound starch granules, and inaccessible to the digesting enzyme. Here there can be no doubt that very-fine grinding of the test sample improves the predictive accuracy of the in vitro test. Whether the same would be true for the poorer qualities of fish meal and meat meal, for example, is uncertain. If combined with pronase digestion, the effect of finer grinding of such test materials is likely to be very small (see Tables 1 and 2) and for the generality of samples it would be satisfactory to grind them to pass through a sieve with a $0.42 \mathrm{~mm}$ aperture ( $40 \mathrm{mesh}$ ), as specified by Boyne et al. (1975).

From Table 2 it may be seen that papain was comparatively ineffective in releasing tryptophan from the test samples. Finer grinding of the test samples gave a marked increase 


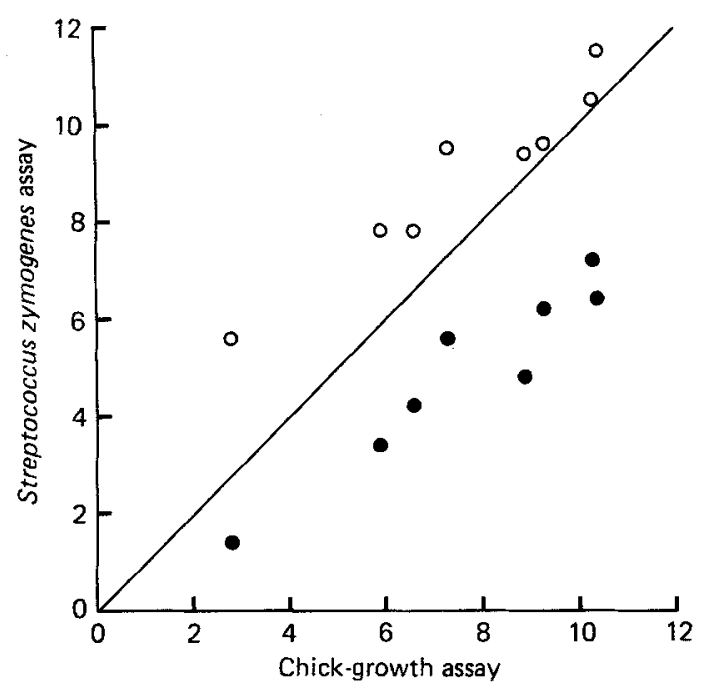

Fig. 3. Available tryptophan (g/160 g nitrogen) in eight fish meals as determined with Streptococcus zymogenes following predigestion with pronase $(O)$ or papain $(O)$, in relation to chick-growth-assay values. The line on the graph indicates equality of values.

in the assay results, but use of pronase instead of papain for predigestion gave still higher results, which were much the same whether or not the samples were finely ground. Both enzymes gave results that were highly correlated with the chick-growth assays (papain, $r$ 0.95 ; pronase, $r 0.96 ; P<0.001$ ), but the papain values averaged $36 \%$ lower and the pronase $16 \%$ higher. This is illustrated in Fig. 3.

Atkinson \& Carpenter (1970) and Boyne et al. (1975) reported similarly, that Strep. zymogenes assays in which papain was used for the predigestion gave lower values for tryptophan than did chick-growth assays.

It may be that the higher results with pronase will tend to err in the other direction, and this remains to be investigated further. There is no doubt, however, that in the assay of tryptophan, as of methionine, pronase is to be preferred as the digesting enzyme. With its use the influence of fineness of grinding of the test samples is less critical (although with cereals, fine grinding is still important), and the assay values are closer to those of the chick bioassays.

Fig. 4 shows the values for DBL and for available lysine as measured microbiologically with Tetrahymena and in chick-growth assays. All three methods gave broadly similar results (DBL $v$. chick assay, $r 0.99, P<0.001$; DBL $v$. Tetrahymena, $r 0.90, P<0.01$; Tetrahymena $v$. chick assay, $r 0.85, P<0.01$ ). However, the Tetrahymena and DBL values for the sub-standard fish meals $\mathrm{C}$ and $\mathrm{G}$ were notably higher than the chick-assay values. Possible reasons for this may be inferred from a report by Hurrell et al. (1983) on the measurement of available lysine in heat-damaged milk powders containing Maillard-reaction products. A proportion of the lysine in these milk powders was present as lactulosyl lysine, which has little or no lysine activity for man or the rat but was highly available as a lysine source for Tetrahymena. Similarly, the DBL procedure also failed to reveal the full extent of lysine damage in milk powders containing lactulosyl lysine, which is still sufficiently basic to bind strongly with the test reagent, Acid Orange 12.

Like these milk powders, heat-damaged fish meal contains products of the interaction of protein and reducing sugars, including deoxyketosyl lysine, and their presence may hinder 


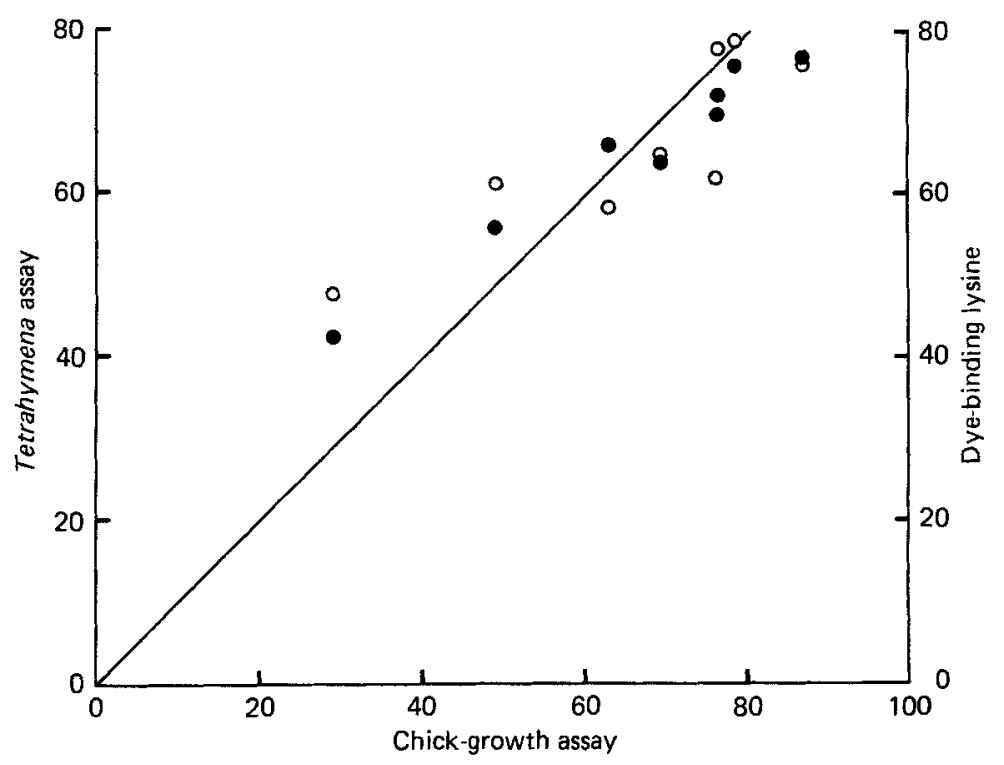

Fig. 4. Available lysine (g/160 g nitrogen) in eight fish meals as determined with Tetrahymena pyriformis (O) and by the dye-binding procedure $(\Theta)$, in relation to chick-growth-assay values. The line on the graph indicates equality of values.

the access of intestinal peptidases to adjacent peptide bonds and result in an accumulation of unavailable peptides in the intestine. Other 'unavailable' peptides result in a similar manner from the formation during heating of new intramolecular linkages that are not amenable to enzymic hydrolysis, and involve mainly lysine, and glutamine and asparagine and the corresponding acids (Ford, 1973). The release of such 'unavailable' peptide material may account for the seeming anomaly, that finer grinding of the poor-quality fish meal $\mathrm{C}$ actually reduced the digestibility (Table 3 ). It may be that the finer-ground meal was in fact more completely digested and so released a higher concentration of 'unavailable'peptide into the intestine. A consequence of this could have been to increase the losses of endogenous protein, of which there is a considerable secretion into the gut. It is normally digested and reabsorbed along with the food protein, but Buraczewski (1966) suggested that the presence of unavailable food protein residues might retard this process. In evidence for this, he reported that in rats given heat-damaged fish meal, the proteolytic activity of the middle and distal lengths of the small intestine was nearly twice that in rats given unheated meal. A more surprising finding was that the content of free amino acids and small peptides in these rats was much higher than in rats given unheated fish meal, and yet the levels of free amino acids in the portal blood were much lower (Buraczewski et al. 1967). A possible explanation for this finding is that the presence of unavailable peptides in high concentration blocks a mechanism involved in the transport of amino acids or small peptides across the mucosal barrier. Support for this suggestion comes from experiments on the influence of unavailable peptides on the uptake of $\left[{ }^{14} \mathrm{C}\right]$ leucine by everted sacs of rat small intestine. Shorrock \& Ford (1978) found that unavailable peptides, isolated from an enzymic digest of heat-damaged fish meal, strongly depressed the uptake of leucine.

A further consideration in the evaluation of the Tetrahymena assay for available lysine, and yet another possible explanation for the higher microbiological assay values for lysine in the heat-damaged fish meals $\mathrm{C}$ and $\mathrm{G}$, is that Tetrahymena can utilize lysinoalanine as 
a source of lysine whereas, in general, higher animals do not have this ability (Sternberg \& Kim, 1979).

Besides comparing microbiological and chick growth assays for amino acid availability, an objective in the present work was to assess the ileal analysis technique as applied in the measurement of protein and amino acid digestibility. Amino acid digestibility coefficients mostly exceeded the corresponding protein digestibility values (Table 3(a)), as also did the biological availability of lysine and methionine in the good-quality fish meals A and B (Table 4). It appeared, therefore, that the digestibility of protein may be lower than the availabilities of its constituent amino acids, which is nonsensical. A likely explanation is that the ileal contents contained a significant proportion of non-amino acid- $\mathrm{N}$, and indeed in the amino acid analysis the recovery of $\mathrm{N}$ in the form of amino acids was only about $64 \%$ (range $55-82 \%$ ). To the extent that this non-protein- $\mathrm{N}$ was of endogenous origin, it would result in an underestimation of crude protein digestibility but would not influence the corresponding estimates of amino acid digestibility. We conclude that the ileal analysis technique may give a better measure of amino acid than of protein digestibility.

In recent years the content of fish meal in pig and poultry rations has generally fallen and that of cheaper alternative vegetable-protein sources has increased. In these circumstances, the fish meal's contribution of available methionine and tryptophan assumes greater importance and our conclusions concerning the present status of the Strep. zymogenes assays for these two amino acids may be of interest. If there are problems in the assays, they concern the accuracy rather than the precision of the results. Our knowledge of the accuracy of in vitro assays is limited by the comparatively low precision of biological assays, which we accept as providing the definitive answers. In Table 4 we see that the standard errors in our chick-growth assays represented at least 5-13\% of the availabilities, and given this typical situation it seems that we have reached a point at which further improvement in the predictive accuracy of the microbiological tests would be difficult to establish. From experience with a broad range of foods and feedstuffs, including meat meals, fish meals, soya-bean and other vegetable proteins, milk products, pulses and cereals, we consider that for practical purposes of routine monitoring and in-house control of product quality, the microbiological assay procedures for available methionine and tryptophan may now be recommended as giving a sensitive and reliable prediction of biological availability for the growing chicken. Against this is their tendency to over-rate grossly heat-damaged samples which, among fish meals, would certainly be detected from their physical characteristics and graded for use as fertilizer. The question of the antinutritive effects of such severely-heated food proteins has not been well studied and should repay further detailed investigation, particularly in connection with human nutrition and the effects of commercial and domestic heat treatment of mixed foods.

There remain questions concerning the use of the growing chick as our animal model. It is to be expected that results of biological tests for protein quality might vary significantly with the species of animal used in the assays. The same might be true to a lesser degree for assays of available amino acids, but there is, as yet, little comparative information.

The fish meals were kindly provided by Dr Stuart Barlow.

\section{REFERENCES}

Achinewhu, S. C. \& Hewitt, D. (1979). British Journal of Nutrition 41, 559-571

Atkinson, J. \& Carpenter, K. J. (1970). Journal of the Science of Food and Agriculture 21, 366-372.

Barlow, S. M., Collier, G. S., Juritz, J. M., Burt, J. R., Opstvedt, J. \& Miller, E. L. (1984). Journal of the Science of Food and Agriculture 35, 154-164.

Boyne, A. W., Ford, J. E., Hewitt, D. \& Shrimpton, D. (1975). British Journal of Nutrition 34, $153-162$.

Buraczewski, S. (1966). Factors affecting amino acid levels in the blood. PhD Thesis, University of Reading. 
Buraczewski, S., Buraczewska, L. \& Ford, J. E. (1967). Acta Biochimica Polonica 14, 121-133.

Finney, D. J. (1978). Statistical Methods in Biological Assay, 3rd ed. London and High Wycombe: Charles Griffin $\&$ Co. Ltd.

Ford, J. E. (1964). British Journal of Nutrition 18, 449-460.

Ford, J. E. (1973). In Proteins in Human Nutrition, pp. 515-529 [J. W. G. Porter and B. A. Rolls, editors]. London: Academic Press.

Ford, J. E. \& Hewitt, D. (1979). British Journal of Nutrition 42, 325-340.

Harwood, E. J. \& Shrimpton, D. H. (1969). Proceedings of the Nutrition Society 28, 66A-67A.

Hewitt, D., Coates, M. E., Kakade, M. L. \& Liener, I. E. (1973). British Journal of Nutrition 29, 423-435.

Hurrell, R. F., Finot, P. A. \& Ford, J. E. (1983). British Journal of Nutrition 49, 343-354.

Hurrell, R. F., Lerman, P. \& Carpenter, K. J. (1979). Journal of Food Science 44, 1221-1231.

Jacobsen, E. E., Moller, A., Nielsen, J. J., Schmidtsdorff, W. \& Weidner, K. E. (1972). International Association of Fish Meal Manufacturers, 12th Annual Conference, Rome. Potters Bar, Herts EN6 3AR, England: IAFMM.

Miller, E. L. (1967). Journal of the Science of Food and Agriculture 18, 381-386.

Miller, E. L., Carpenter, K. J., Morgan, C. B. \& Boyne, A. W. (1965). British Journal of Nutrition 19, $249-267$.

Shorrock, C. (1976). British Journal of Nutrition 35, 333-341.

Shorrock, C. \& Ford, J. E. (1978). British Journal of Nutrition 40, 185-191.

Slump, P. \& Schreuder, H. A. W. (1969). Analytical Biochemistry 27, 182-185.

Spies, J. R. (1967). Analytical Chemistry 39, 1412-1416.

Sternberg, M. \& Kim, C. Y. (1979). Journal of Agricultural and Food Chemistry 27, 1130-1132.

Varnish, S. A. \& Carpenter, K. J. (1975). British Journal of Nutrition 34, 339-349. 